\title{
Credit risk management and profitability: empirical evidence on Ethiopian commercial banks
}

\author{
Shibiru Tade Kidane \\ Department of Accounting and Finance, Faculty of Business and Economics, Ambo \\ University, Ethiopia
}

Correspondence author email: shibe2012@gmail.com

\begin{tabular}{|l|l|l|l|l|}
\hline DOI: & Received: & Revised: & Accepted: & Published: \\
10.22437/ppd.v8i4.10225 & 06.08 .2020 & 16.09 .2020 & 03.11 .2020 & 07.11 .2020 \\
\hline
\end{tabular}

\begin{abstract}
The aim of the study was to assess the impact of credit risk management on the profitability commercial banks in Ethiopia. Secondary data was gathered from National Bank of Ethiopia for ten year periods (2010-2019). The study adopted Correlation analysis and fixed effect Model. Return on Asset was used to measure profitability of commercial banks, bank specific factors(Capital adequacy, Loan and Advances to total deposit, Non- Performing Loans, Bank size and Liquidity and macroeconomic factors (Inflation and Gross Domestic Product) as indicators of credit risk management. The findings showed that Credit Risk Management in terms of bank specific and macroeconomic factors has significant impact on profitability of commercial banks in Ethiopia. Also the result displayed that profitability of commercial banks is not affected by the amount of non- performing loans during the study. The study recommended that banks' credit risk management should not give due devotion only to the internal factors but also to external factors exclusively (Gross Domestic Product and Inflation) in order to minimize their negative impact on profitability of commercial banks in Ethiopia.
\end{abstract}

Keywords: Bank specific, Commercial banks, Credit risk management, Profitability

JEL Classifications: G21, E44, L25

\section{INTRODUCTION}

Banking industries have achieved great fame in the Ethiopian economic growth. They play principal role in granting credit facilities for financing of agriculture, industrial and commercial activities. The probability of incurring losses resulting from non- payment of loans by debtors known as credit risk is mostly encountered in the financial institutions of Ethiopia. The increased competition associated with the process of capitalization, liberalization and globalization and the attempts of Ethiopian banks to increase their presence in other markets may have affected the efficiency and credit risk of the Ethiopian banking institutions (Shibiru \& Mebratu, 2017). 
According to Girma (2011), banking institution in Ethiopia has the largest assets in the loan portfolio and the primary source of credit risk in Ethiopian's banking industries and are most likely to make a loss. When the commercial banks have higher credit risk, the greater credit payments to be charged by the banks.

If the credit risk management is success, the profit level will be suitable. In difference, if the credit risk management is unfortunate, the profit level will be justly low. Because the less the bank's loss from credits, the more the banks gain (Hosna et al., 2009). As per the study of Kargi (2011) and Fredrick (2010), credit risk management is an important indicator of banks financial performance. They stated that the degree of the impact of credit risk management strongly depends on regulatory environment in which banks operate.

In a study of the Kenyan Banking Industry, Kithinji (2010) presented that there is an indirect relationship between credit risk management and profitability of banks. Other empirical studies made in Qatar bank by Achou \& Tengue (2008) showed that better credit risk management result in better bank performance. They concluded that credit risk management has crucial importance for banks safeguard the asset of the bank and protect investor's interest. Also they further indicated that banks with strong credit risk management policies tend to incur lower loan default and high return.

Macroeconomic factors affect bank's performance. Adverse macroeconomic conditions upset banks by increasing the amount of credit risk. Gross domestic product rate, inflation and interest rate are the main economic factors that determine credit risk management of the banks (Athanasoglou et al., 2008). The researchers stated that gross domestic product, inflation and interest rate significantly impacts on profitability of banks.

Credit risk management is a structured method to manage risk through risk assessment and developing strategies by screening and monitoring, long-term customer relationship, credit rationing and collateral requirements (Tefera, 2011). Consistently, Shibiru \& Mebratu (2017), credit risk management has significant impact on performance of Ethiopian private commercial banks. Bank specific factors: Capital adequacy, loan growth, Non-Performing Loans, bank size and liquidity had significantly affects banks. The researchers recommended that the bank's Credit Risk Management should assess risk and develop strategies to minimize credit risk incidence.

Relatively very scanty studies have empirically examined credit risk management and profitability/performance of commercial banks in Ethiopia and arrive at divergent results (Tefera, 2011, Girma, 2011, Shibiru \& Mebratu, 2017). Variables considered by researchers to capture the impact of credit risk management on profitability were only specific factors and concerning with the literature, were not found sufficient in prior studies in the country. Besides, lack of thorough investigation of macroeconomic factors that determine credit risk management of commercial banks are also been observed in prior studies. So, in current investigation both bank specific and macroeconomics factors were considered to grasp the impact of credit risk management on profitability of commercial banks in Ethiopia (2010 to 2019) and to fill the lacuna existing in the local literature. 


\section{LITERATURE REVIEW}

Funso et al., (2012) used Non-Performing Loans as a strong Credit Risk Management indicator. Efficient Credit Risk Management supports the fact that lower NPLR is correlated with lower credit risk and lower deposit rate. However, in long run, high deposit rate increases the deposit base in order to fund relatively high credit risk and consequently increases NPLR. Therefore, allocation of the available fund and its credit risk management heavily depend on how the credit risk is held and differentiated to decrease the NPL amount.

Kosmidou (2008) tried to identify the impact of CRM in terms of Gross Domestic Product on bank profitability. The result showed that Gross Domestic Product has positive and strong impact on bank profitability due to the default risk is lower in rise than in recession economy. Mekasha (2011), Kurawa \& Garba (2014) found that credit risk management has positive and significant on profitability of banks. But Tefera (2011) argued that credit risk management has negative and significant impact on the profitability of the commercial banks. Other researchers like Epured \& Lafuente (2012) found that credit risk management does not influenced on banks profitability. Ani et al., (2012) revealed positive and significant relationship between loan growth and profitability of banks. They suggested that the growth of loans measure income source and liquidity of bank. But the result was contracted by Kargi (2012) and Rufai(2013). They found that a higher loan ratio actually impacts profitability negatively.

Regarding the impact of non-performing loans on profitability of financial institutions; Kadubo \& Musyoki (2011) in Kenya, Kargi (2012) and Rufai (2013) in Nigeria, Kaaya \& Pastory (2013) in Tanzania and Shibiru \& Mebratu (2017) in Ethiopia found that non-performing loan had negatively impact on profitability of banks. However, these studies not in line with the findings of Epure \& Lafuernte (2013). They claimed that credit risk management (non- performing loans) has no impact on financial performance of financial institutions and recommended that banks should follow regulatory changes rather than focusing on credit risk management.

Fredrick (2010) valued the impact of credit risk management on financial performance of banks is robust. They concluded that accomplishment of banks depend on credit risk management effectiveness. Also, Kenneth \& Charles (2013) on commercial banks in Nigeria using Return On Asset as a measure of financial performance, it was understood that credit risk management have significant impact on financial performance of banks in Nigeria.

Kithinji (2010) explored the impact of credit risk management in Kenyan banks between 2004 to 2008 found majority of commercial banks are not affected by credit risk management. Lastly, the study recommended that banks should consider on other variables rather than on non- performing loans. Belayneh (2011) specified that Gross Domestic Product is the only significant factors from macroeconomic indicators. He stated that Gross Domestic Product of the country makes commercial banks to be more profitable. A high growth rate may strengthen the debt servicing capacity of domestic borrowers, and therefore contribute to less credit risk. The study also examined a negative and strongly significant impact of credit risk on Ethiopian commercial banks.

The impact of credit risk management on performance of private commercial banks in Ethiopia was examined by Shibiru \& Mebratu (2017) for period 2000 to 3013. 
Fixed Effect model was adopted. Secondary data was gathered from audited financial statement of 6 selected private banks. The result suggested that Credit Risk Management (capital adequacy, Non-Performing Loans, Bank size and Liquidity) have significant impact on financial performance of private banks. Similarly, Fredrick (2010) used Secondary data collected from annual reports of the six selected banks. The study employed the random Effect Model. The results presented that Credit Risk Management have significant relationship with the profitability of commercial banks in Ghana.

\section{METHODS}

This section deals with the methods of data collection and the methodology employed in the research analysis.

Data

Secondary data was collected from National bank of Ethiopia, the country's central bank. Both Bank specific factors and Macroeconomic factors were gathered from National bank of Ethiopia for the ten (10) years of old commercial banks covering from the period of $2010-2019$ G.C.

\section{Sampling technique and sample size}

Ten commercial banks of Ethiopia that have audited annual reports for the year 2010 and onwards were selected due to their age. Hence, the ten purposively selected commercial banks (Awash Bank, Abyssinia Bank, Commercial Bank of Ethiopia, Cooperative Bank of Oromia, Dashen Bank, Lion International Bank, Nib International Bank, Oromia International Bank, United Bank and Wogagen Bank.

\section{Data analysis}

After data collection processes have been accomplished, fixed effect regression model were employed. STATA version 13 was used for analyzing the data.

\section{Model specification test}

This study is modeled according to the work of Shibiru \& Mebratu (2017), which investigated the impact of credit risk management on the performance of 6 (six) private old commercial banks from the year of 2000 to 2013. On recent study, researcher modified the model on the right side by adding the macroeconomic factors (Gross Domestic Product and Inflation) as exploratory variables of credit risk management to assess credit risk management impact on profitability of ten (10) commercial banks in Ethiopia.

The model is specified as:

$$
\mathrm{ROA}_{i t}=\beta_{0+} \beta_{1} \mathrm{CAR}_{\mathrm{it}}+\beta_{2} \mathrm{LATD}_{3} \beta_{3} \mathrm{NPLR}_{\mathrm{it}}+\beta_{3} \mathrm{LR}_{\mathrm{it}}-\beta_{5} \mathrm{LOTA}_{\mathrm{it}}-\beta_{6} \mathrm{INF}+\beta_{7} \mathrm{GDP}+\varepsilon_{\mathrm{it}}
$$

Table 1. Variables description and expected results

\begin{tabular}{llc}
\hline Variable & Explanation & Expected Sign \\
\hline ROA & A ratio of Bank's Net Income After Tax Against its Total Asset & \\
CAR & A Ratio of Net Income After Tax to Total Capital of Bank & $(+)$ \\
LATD & A Ratio of Loans and Advances to Total Deposits of Bank & $(+)$ \\
NPLR & Aggregate Non-Performing Loans to Total Loans & $(-)$ \\
LR & Cash at Safe and Cash at Bank to Total Asset of Bank & $(+)$ \\
LOTA & Natural Log. of Total Asset of Bank (Bank Size) & $(-)$ \\
INF & Average Inflation Rate & $(-)$ \\
GDP & Percentage Growth Rate of GDP & $(+)$ \\
\hline
\end{tabular}




\section{RESULTS AND DISCUSSION}

This part of the study portrays the inferential analysis that shows the empirical evidence on the impact of credit risk management on the profitability of selected commercial banks in Ethiopia.

\section{Multi collinearity test}

The multicollinearity problems of independent variables of commercial banks in Ethiopia (Capital adequacy, loans and advances to total deposits, Non- performing Loans, Liquidity, Bank size, Inflation and Gross Domestic Product) was made using VIF and Tolerance. If tolerance limit is greater than 0.10 and the VIF is below 10, multicollinearity problem doesn't exist.

Table 2. Collinearity statistics

\begin{tabular}{lcc}
\hline Variable & Tolerance & VIF \\
\hline CAR & 1.34 & 0.748500 \\
LATD & 1.51 & 0.661843 \\
NPL & 1.09 & 0.919237 \\
LR & 1.69 & 0.590701 \\
LOTA & 1.20 & 0.830261 \\
INF. & 1.23 & 0.815378 \\
GDP & 1.20 & 0.834387 \\
\hline
\end{tabular}

As shown on Table 2, since the tolerance limit is greater than 0.10 and the VIF is below 10, multicollinearity problem doesn't exist. Therefore, the model is free from multicollinearity problems.

\section{Hypothesis test}

Brooks (2008) explained that Wald- coefficient restriction test was used to test the multiple hypotheses. It shows that the coefficients of explanatory variables are different from zero. If the Wald test presents the P- value is less than 0.05 , then explanatory variables have an impact on dependent variable.

Table 4. Wald- Coefficient test

\begin{tabular}{lc}
\hline Statistic & ROA Model \\
\hline F- statistic $(7,92)$ & 28.35 \\
Probability & 0.0000 \\
\hline
\end{tabular}

As shown on table 4, the independent variables (CAR, LATD, NPL, LR, LOTA, INF. And GDP) have an impact on the dependent variable (ROA) of commercial banks in Ethiopia since p-value is less than 5 percent level of significance.

\section{Hausman specification test}

Running a Hausman Specification test at five (5) percent level allows the researcher to select between fixed effect and random effect models. The Hausman Test evaluates the Null hypothesis that the coefficient estimated by the random effect estimator is the same as the ones estimated by the constant fixed effect estimator. If the Hausman test is significant ( $\mathrm{P}-$ Value $\leq 5$ percent), then the fixed effects model will be used (Brooks, 2008). In this study, as indicated by the Hausman test (Table 5), fixed 
effect model is to be preferred as the p-value $=0.0000$ which is less than 5 percent . Thus fixed effect was used in analysis.

Table 5. Hausman test: Fixed effect model Vs Random effect model

\begin{tabular}{llll}
\hline Hausman Test: & H0: REM $>$ FEM & \multicolumn{2}{c}{ Ha: FEM $>$ REM } \\
\hline Model & Prob.(F-statistic) & Chi-sq statistic $\left(\chi^{2}\right)$ & Preferred model \\
\hline ROA & 0.0000 & 90.92 & Fixed Effect model \\
\hline
\end{tabular}

\section{The result of the Fixed Effect analysis}

This section depicts the fixed effect regression model analysis of the impact of credit risk management on profitability of Commercial Banks in Ethiopia.

Table 6. ROA model: Fixed Effect regression result

\begin{tabular}{lcccc}
\hline Variable & Coef. & Std. Err. & $\mathrm{t}$ & $\mathrm{P}>|\mathrm{t}|$ \\
\hline CAR & 1.199446 & .0879236 & 13.64 & $0.000^{* *}$ \\
LATD & -.041944 & .0041951 & -10.00 & $0.000^{* *}$ \\
NPL & .0069658 & .0056383 & 1.24 & 0.220 \\
LOTA & -.0111432 & .0040188 & -2.77 & $0.007^{*}$ \\
LR & -.2149658 & .0564897 & -3.81 & $0.000^{* *}$ \\
INFL & -.0030490 & .0012505 & -0.24 & $0.018^{*}$ \\
GDP & $-1.94 \mathrm{e}-06$ & $1.01 \mathrm{e}-06$ & -1.93 & $0.050^{*}$ \\
Cons. & .3028181 & .0774229 & 3.91 & $0.000^{* *}$ \\
\hline \multicolumn{2}{r}{} & F- statistic $=39.02$ & Prob.(F- statistic $)=0.0000$ \\
\hline
\end{tabular}

Fixed effect regression result shows that the positive and significant impact of capital adequacy on the profitability of commercial banks in Ethiopia. The coefficient of capital adequacy is 1.199446 and its p-value is 0.000 . This showed that as capital adequacy increased by one unit, return on asset (ROA) of sampled of Ethiopian commercial banks was increased by 1.199446 units. This finding is consistent with the previous studies by Hakim \& Naieme (2002), Li Yuqi (2007), Birhanu (2012) and Kenneth \& Charles (2013), but inconsistent with the finding of Berger (2000).

Credit risk management has negative impact on profitability of commercial banks in Ethiopia in terms of loan and advances to total deposit at $1 \%$ level of significance. The coefficient value of LATD (i.e. -.041944) indicates a percentage rise/decline in LATD ratio of commercial banks result in high proportionate (i.e. 4.19\%) rise/decline in ROA of commercial banks in Ethiopia. The study debated that this exposed to higher credit defaults level of commercial banks in Ethiopia. The result is consistent with the findings of Vong \& Chan (2000), Kolapo et al., (2012). But disagrees with the findings of Ahmed et al., (1998) and Iloska (2014).

The result revealed that NPL has positive and insignificant impact on profitability of commercial banks in Ethiopia. For a $1 \%$ increase or decrease in NPL, the banks increase or decrease their profit by 0.7 present. The result was in line by the prior findings of Kithinji (2010), Afriyie et al. (2013) and Epure \& Lafuente (2013) but contradicted with the findings of Achou \& Tenguh (2008), Hosna et al. (2009), Mekasha (2011),Tefera (2011), Kargi (2012) and Shibiru \& Mebratu (2017). They concluded that NPL ratio has negative and significant impact on profitability of banks. But the study showed that profitability of commercial banks was not affected by non- 
performing loans during the study and the study suggested that commercial banks of Ethiopia should focus on other factors and banking policy than focusing more on nonperforming loans.

Bank size has negative and significant impact on profitability of banks ( $\mathrm{P}$-value $=$ $0.007)$ at $5 \%$ significance level. This implies that as bank size increased by $1 \%$, return on asset decreased by $1.11 \%$ due to the existence of managerial inefficiency to manage their assets during the study in commercial banks of Ethiopia. The result of this study is in line with the result of Birhanu (2012) in Ethiopia, Ani et al. (2012) in Nigeria and Epure \& Lafuente (2013) in Spain. Nonetheless, the result of this study is contradicted with many previous studies of Alper \& Anbar (2011),Agyei et al. (2012) and Kaaya \& Pastory (2013).

The result revealed that credit risk management in terms of liquidity ratio has significant negative impact on profitability of banks at $1 \%$ level of significance. It indicates that as the level of liquidity ratio increased by 1 percent, and then ROA is decreased by 21.50 percent. The result proposed that commercial banks of Ethiopia have an inability to meet its financial obligations at a reasonable cost and more exposed to credit risk and liquidity risk. The result is consistent with the finding of Yuqi (2007) and unpredictable with the prior studies of Hakim and Naieme (2002), Kurawa \& Garba (2011), Adorkwa (2011), Megeid (2013), Iloska (2014) and Shibiru \& Mebratu (2017).

Inflation refers to the continued increase in the general prices of goods and services in an economy over time. The impact of inflation on profitability is ambiguous. It has negative impact on profitability in banks. It weakens borrowers' ability to service debt by reducing the real value of outstanding loans. According to the regression result, inflation is significantly negatively impact on profitability of commercial banks in Ethiopia ( $\mathrm{PV}=0.018$ ). The researcher argued that this is probably due to the fact that inflation could affect the value for money, purchasing power of people and the real interest rate that banks charge and receive. The result of the study was similar with the finding of (Nkusu, 2011) but dissimilar with the finding Richard (2011).

Finally, Economic growth (GDP) had negative significant impact on profitability of commercial banks ( $\mathrm{p}$-value $=0.050$ ) at $5 \%$ level of significance. Like with the empirical evidence, as GDP of the country increased the profitability of Ethiopian commercial banks decreased and vice versa. If GDP growth is high, the loan request increases and thus the commercial banks of Ethiopia exposed to default risks. The result is in line with the findings of Beck et al.(2013) but not in line with the finding of Birhanu (2012) found that GDP has positive and significant effect on profitability of commercial banks in Ethiopia. Also Fredrick (2010) found that there was no significant relationship between GDP and banks profitability.

\section{CONCLUSION AND RECOMMENDATION}

\section{Conclusions}

The study assessed the impact of credit risk management on profitability of commercial banks in Ethiopia. This study concluded that capital adequacy, loan growth, liquidity, bank size, Inflation and Growth Domestic Product used as a proxy for credit 
risk management had strong impact on the profitability of commercial banks in Ethiopia.

\section{Recommendations}

The study suggested that commercial banks in Ethiopia should not only concentrated on enhancing their capacity in credit analysis and loan administration but also engrossed on macroeconomic factors that were significantly impact on the profitability of commercial banks in Ethiopia.

\section{REFERENCES}

Achou, F.T., \& Tenguh, C.N. (2008). Bank performance and credit risk management. [Master's thesis]. School of Technology and Society, University of S koved.

Adarkwa, O.R. (2011). Risk management and bank performance: a case study of first Atlantic Merchant Bank Ghana limited. [Master's thesis]. Kwame Nkrumah University.

Afriyie, O.H \& Akotey, O.J. (2010). Credit risk management and profitability of selected rural and community banks in Ghana. Working paper. Catholic University College of Ghana.

Ahmed, A.S., Takeda, C., \& Thomas, S. (1998). Bank loan loss provision: A reexamination of capital management and signaling effects. Working paper, Department of accounting, Syracuse University.

Alper \& Anbar (2011). Bank specific and macroeconomic determinants of commercial banks Profitability: Empirical Evidence from Turkey. Business and Economics Researc Journal, 2(2), 139-152.

Ani, W.U., Ugwunta, D.O., Ezeudu, I.J. \& Ugwuanyi, G.O. (2012). An empirical assessment of the determinants of bank profitability in Nigeria: Bank characteristics panel Evidence. Journal of Accounting and Taxation, 4(3), 38-43.

Athanasoglou, P.P., Brissimis, S.N., \& Delis, M.D. (2008). Bank-specific, industryspecific and macroeconomic determinants of bank profitability. Journal of International Financial Markets, Institutions and Money, 18(2), 121-136

Beck, R., Jakubik, P., \& Piloui, A. 2013). Non-performing Loans: What Matters in Addition to the Economic Cycle?, Working paper, European Central Bank, Frankfurt, Germany.

Belayneh, H. (2011). Determinants of Commercial Banks Profitability: An empirical study on Ethiopian Commercial Banks. [Doctoral Dissertation]. Addis Ababa University.

Berger, A.N (2000). The integration of the financial services industry: Where are the efficiencies? FEDS Paper, No. 36.

Birhanu, T.M. (2012). Determinants of commercial banks profitability: An empirical evidence from the Commercial Banks of Ethiopia. [Master's thesis]. Accounting and Finance Department, Addis Ababa University.

Boahene, S., Dasah, J., \& Agyei, S. (2012). Credit risk and profitability of selected banks in Ghana. Research Journal of Finance and Accounting, 3(7), 6 - 14.

Brooks, C. (2008). Introductory Econometrics for Finance. Cambridge University Press 
Charles, O. \& Kenneth, O.U (2013). Impact of credit risk management and capital adequacy of financial performance of commercial banks in Kenya. Journal emerging issues in economics, finance and banking, 2(3), 703-717.

Epure, M. \& Lafuente, E. (2013). Monitoring bank performance in the presence of risks. Working paper. Barcelona Graduate School of Economics.

Fredrick, O. (2010). The impact of credit risk management on financial performance of Commercial banks in Kenya. DBA African management review, 3(1), 22-37.

Funso, K.T., Kolade, A.R., \& Ojo, O.M. (2012). Credit risk and commercial banks performance in Nigeria. Australian Journal of Business and Management Research, 2(2), 31-38)

Girma, M. (2011). Credit risk management and its impact on performance of Ethiopian Commercial banks. [Master's thesis]. Addis Ababa University.

Hakim, S. \& Neaime, S. (2002). Performance and credit risk in Banking: A Comparison study for Egypt and Lebanon. ERF Working paper

Hosna, A.B. et al. (2009). Credit Risk Management and Profitability in Commercial Banks in Sweden, [Master's thesis]. University of Gothenburg, Graduate School of Business, Economics and Law, Master of Science in Accounting.

Iloska, N.(2014). An analysis of bank profitability in Macedonia, Journal of Applied Economics and Business. Journal of Applied Economics and Business, 2(1), 31 50

Kaaya, I. \& Pastory, D. (2013). Credit risk and commercial banks performance in Tanzania. Research Journal of Finance and Accounting, 4(16), 55 - 62

Kadubo, A.S. \& Musyoki, D.(2011). The impact of credit risk management on the financial Performance in Kenya', International Journal of Business and Public Management, 2(2),72-80.

Kargi, S.H. (2011). Credit risk \& performance of Nigerian Banks, Ahmadu Bello University.

Kithinji, M.A. (2010). Credit risk management and profitability of commercial banks in Kenya. School of Business, University of Nairobi.

Kurawa, M. J. \& Garba, S. (2014). An Evaluation of the Effect of Credit Risk Management on the profitability of Nigerian Banks. Journal of Modern Accounting and Auditing, 10(1), 104 - 115

Liyuqi, (2007). Determinants of Banks profitability and its implication on risk management practices: Panel Evidence from the UK in the Period 1999-2006, [Doctoral dissertation]. University of Nothingham.

Megeid, S.A. (2013). The impact of effective credit risk management on commercial banks liquidity Performance in case of Egypt', International Journal of Accounting and Financial Management Research, 3(2), 13 - 32

Richard, E. (2011). Factors that cause non-performing loans in commercial banks in Tanzania and strategies to resolve them, Journal of Management Policy and Practice, 12(7), 50-58.

Rufai, A.S. (2013). Efficacy of Credit Risk Management on the Performance of Banks in Nigeria. Global Journal of Management and Business Research Administration and Management, 13(4), 1 - 12 
Shibiru, T. \& Mebratu, N. (2017). Impact of Credit Risk Management on Financial Performance of Private Commercial banks in Ethiopia, Journal of Economics and Sustainable Development, 8(15), 47 - 52

Tefera, T. (2011). Credit risk management and profitability of commercial banks in Ethiopia. [Master's thesis]. Addis Ababa University.

Vong \& Chan, (2005). Loans and profitability of banks in Macao. AMCM quarterly bulletin, 15, 91 - 107 